\title{
Orientation about sexually transmitted infections to young students from the education in health program
}

\author{
Silva, J.S1, Sousa, J.R2, Rosário, D.D.S3, Sousa, J.R.A4, Piauiense, J.N.F5, Amador, B.M6
}

1,4Residente de Farmácia-UFPA; 2Residente de Fisioterapia-UFPA; 3Residente de EnfermagemUFPA; 5Residente de Biomedicina - UFPA; 6Mestranda em gestão e saúde-UFPA.

\begin{abstract}
Introduction: The sexually transmitted infections are a worldwide concern. The rates of some infections are increasing in groups of people that were not affected by them in the past, therefore, this increase demonstrates many vulnerabilities in those groups, even though that are a circumstantial number of promotion and prevention of health in the actual health system. Objetive: To describe an action of education in health about sexually transmitted infections (Syphilis and Human Papillomavirus - HPV) to young adults from a public school of the state of Pará. Methodology: This study is a descriptive experience report, developed by a multiprofessional team of Women's and Children's Health residents. The education in health action was performed using a pretest with closed questions about syphilis and HPV. These questions were about clinical epidemiological information about the diseases. After this pretest, a lecture was performed for the students about the diseases and the correct methods of preventing those. The students were divided into groups and they were told to make a poster with images about what they have had understood about the lectures, the clinical aspects of the diseases. Results and Discussion: The students had a satisfactory perception of the sexually transmitted diseases, which was demonstrated by the answers of the pretest and the poster they had made. The action showed that students were receptive and aware that even with lectures and campaigns, the risks of infection were still a risk, and so they sought preventive methods that would protect them regularly. Conclusion: Health orientation in schools is a good method to aware young adult's students about the health-disease process. The action could improve the relationship between the multiprofessional residents and spread substantial information about the sexually transmitted diseases to students from the education in health program.

*Correspondence to Author:

Silva, J.S

Residente de Farmácia-UFPA

How to cite this article:

Silva, J.S, Sousa, J.R, Rosário, D.D.S, Sousa, J.R.A, Piauiense, J.N.F5, Amador, B.M.Orientation about sexually transmitted infections to young students from the education in health program.International Research Journal of Health Education, 2018, 1:1

\section{eScîPub}

eSciPub LLC, Houston, TX USA.

Website: http://escipub.com/
\end{abstract}

Keywords: Syphilis; Human Papilommavirus; Health Education 